\title{
"WANT OF VISION"
}

SIR Robert Borden's lectures on the constitutional develop$\checkmark$ ment of Canada, ${ }^{1}$ by this time widely studied and known, are, apart from other merits, of unique value as the judgment passed by a man of action upon events and policy, of the latest and widest phases of which pars magna fuit. No one could speak on the subject-matter of these lectures with such living first-hand authority as the statesman who led Canada, and did much towards leading the whole British Empire, in the memorable years of the Great War and its immediate aftermath.

What follows is not an attempt to add a further and superfluous review of the Canadian Constitutional Studies, but to give a short note, for which these lectures supply a text, on the Canadian view of the constitutional development of Canada, and how far it differs, and why, from what may be called the standpoint of the Mother Country.

What makes the story of Canada on the constitutional sidetaking that side alone-so interesting is that, as we all know, Canada led the Overseas Empire at every step of constitutional development. What Canada did, and what happened to Canada, was, more or less closely, followed elsewhere. The study of the evolution in Canada is a study of the problem generally, for in Canada it was first and most thoroughly worked out through successive stages. At the same time - and the point seems hardly ever to be sufficiently emphasized-the conditions of Canada, in one important respect at any rate, were and are quite peculiar. Canada has had a great foreign, though kindred, nation along its whole land frontier, and this factor, which practically exists nowhere else in the Empire, has, in a very great degree, directly or indirectly, shaped the course of Canadian history and in consequence has largely shaped the course of the other young nations, which have followed along the path marked out by Canada. For instance, to take the most recent illustration,

${ }^{1}$ Sir R. L. Borden, Canadian Constitutional Studies (Toronto, 1922). 
the movement towards separate diplomatic representation for the self-governing Dominions is obviously and immediately the outcome of the neighbourhood of Canada to the United States. The two countries must, from the nature of the case, deal directly with each other.

We have, then, among the numberless contradictory features in the British Commonwealth, the fact that what, to my mind, has been natural and normal development has emanated from the one part of the Empire which has had a special setting, not paralleled elsewhere within the limits of the Empire; and from this fact it may not unfairly be inferred that the Canadian point of view may also possibly be at once partly normal and partly sui generis.

My own view of the British Empire or Commonwealth--for what it is worth-is that the whole thing is utterly unintelligible and inexplicable, unless it is looked at, thought, and written of, in the light of the family analogy. To me it has all been a matter of natural growth, and the peculiar genius of our British stock has lain in following the lines of natural growth. If in a family the young members wish to go more quickly and the parents more slowly, if therefore from time to time they think differently and there is a certain amount of friction, it seems to me quite natural. I do not regard one as right and the other as wrong, I regard them as both right, the problem being to find, as a working proposition, the greatest common measure of the two quantities. Therefore, I should regard the Canadian point of view and the Mother Country point of view, so far as in the past they have not coincided, as both, roughly speaking, natural and right. But, for the present purpose, I want to hold a brief for the Mother Country, simply by way of presenting the other side; for Sir Robert Borden, to a modified extent, and other writers, in a much more pronounced degree (e.g., the recently published Fiscal and Diplomatic Freedom of the British Oversea Dominions) tend to portray the development of Canada from a dependency to a nation as something which was wrung by clearsighted, freedom-loving Canadians from purblind politicians in a repressive Mother Country.

Sir Robert writes of the British North America Act that it "crowned the endeavour of a century, during which the initiative in constitutional development had been taken by Colonial Statesmen". As a general statement, this is quite true, and it is to be hoped that, as it has been in the past, so it will be in the future. 
It is for the young to initiate the moves, and, when Sir Robert makes his interesting criticism on the failure to take steps to carry out the Resolution of the 1917 Conference ("I have yet to learn that since the conclusion of peace their [the Dominions'] right to 'an adequate voice in foreign policy and in foreign relations' has been recognized in any effective or practical way"), I, for one, devoutly hope, in the interests of good understanding, that the method by which such recognition can be given, and which will be at once effective and congenial to the young nations, will be indicated by them, that they will keep the initiative in their hands.

But now let us look at past history. We are told by Sir Robert that Lord Stanley's speech on Canada in the House of Commons in May, 1844, was "insular in its spirit", but "made an irresistible appeal to an audience of imperfect comprehension and limited vision". Sir Charles Metcalfe accepted "the narrow views which then afflicted British statesmen". "In its main aspects the theory of the most powerful intellects among British statesmen three quarters of a century ago was unmistakedly 'unicellular' "- a term derived from, and supported by, a quotation from Maitland. At the time of the passing of the British North America Act, "in the letters of Sir John Macdonald and Sir A. T. Galt we have a curious picture of the attitude of British statesmen of the day; their indifference, their lack of vision, and their apparent relief at the prospect that the Northern half of the North American continent would pass out of the orbit of the British Empire, are astonishing and even bewildering". In 1876 "it was apparent that the wisdom of the Colonial Office had not increased with years". "Sir John Thompson encountered a remarkable and unfortunate lack of vision and comprehension on the part not only of the Colonial Office but of the entire British Government." "This shortsighted view [of Sir Michael Hicks Beach in 1878] soon passed into the desuetude to which equally narrow views of earlier days have been consigned." And so forth. The burden of it all is the shortcomings or worse of the Mother Country, the want of vision on the part of its statesmen. From my own point of view, the true reading of history would admit, as inevitable from the nature of the case, a considerable amount of point in these and other similar charges. Canadians must have known the conditions, the interests, and the outlook of Canada much better than any one outside could know them. But, nevertheless, the statements are half truths 
only, not the whole truth. What is to be said on the other side?

We are all wise after the event. As it has worked out, the evolution has been wondrously successful. But that is no reason for reading our present knowledge into generations long gone and condemning them for not having been more than human. Are we seriously to suppose that Canadians foresaw all that was coming? Are we, again, seriously to suppose that it all came to pass, as the version of history which I am now controverting would incline people to think, not only without the coöperation, but in the teeth, of the Mother Country?

Who were these English politicians, who were so wanting in vision, so loth to give freedom, so much stupider than the Canadians of their day? They were the men who were leading England when, in the middle of the nineteenth century, the world acknowledged the leadership of England in all that was liberal and progressive and made for freedom. They necessarily moved in a wider circle than contemporary Canadians. Is it likely that they were, as they are made out to have been, abnormally narrow and dull? Is it not at least as likely that, if Canadians saw more clearly, it was because their horizon was not broader but narrower, bounded by Canada alone?

The problem was not a fixed problem. It was a fluid problem, shifting like the films of a cinema show. Canada was constantly changing and growing. The Canada of one year was wholly different from the Canada of ten years later, just as a boy of ten is wholly different from a young man of twenty. Because certain institutions proved to be good when they came, it does not follow that they would always have been good, that they were wrongly withheld, that caution in giving them was a mark of stupidity. You do not make a child self-governing from his mother's womb. Should the English dullards have given selfgovernment to Canada from the moment when it became a British possession? No. Should Canadians have been given full responsible government, control of the tariff; and all the rest of it, in 1791? I should say, No. At what psychological moment or moments were the various elements of nationhood to be given, and were they to be given all at once or by instalments? What had the Mother Country to go by except the demand from Canada at any given time and the best estimate that could be formed at the time of the consequences of complying with the demand? 
The Canadian view of Canadian development does not seem to allow for the numberless calls that there were at all times upon the attention of the Mother Country, for its worldwide entanglements and responsibilities. That no doubt was no valid reason for neglecting Canada, but it explains neglect, if there was any. It was a drawback to Canada, the consequence of Canada's membership in the British Empire; but, on the other hand, that membership, so some people think, brought with it certain countervailing advantages. Take the years 1850-1870, during which the Mother Country is supposed to have been somewhat specially wanting in regard for Canada. They were the years of the Crimean War, the Indian Mutiny, and the American Civil War, with its grave danger of a rupture between Great Britain and the United States. Was it wonderful if British statesmen could not concentrate on constitutional development and on Canada? They never could concentrate on Canada. They always had to cast their eyes further afield. Whatever line was taken in regard to Canada had also to be taken elsewhere in the Empire. It was the wider horizon, not the narrower, that was the trouble.

In Canadian criticisms of the past conduct of the Mother Country there is one very singular feature. It will be found that the Mother Country is charged, at one and the same time, with trying to repress or coerce the colonies and with indifference to them, in other words with at once trying to withhold freedom and to give more freedom than the colonies desired-complete independence. Human beings do not usually commit diametrically opposite crimes at the same time.

Biographies, it seems to me, are responsible for a good deal of misunderstanding. A worried statesman, who may have the toothache or a row with his wife or both, has a troublesome political question thrust upon him. He makes some impatient remark, or writes an impatient private letter, and many years afterwards the obiter dictum, like Disraeli's "wretched colonies", is trotted out as a considered opinion, and, what is worse, is exaggerated into being typical of the whole band of statesmen at the time. The expressions may have been more or less justified in reference to the particular time or occasion when they were used. For instance, much is made of Galt's state paper of $\mathbf{1 8 5 9}$ asserting the right of Canada to levy what duties she pleased. At the time the British taxpayer was paying (quite rightly, from my family point of view) between $£ 3$ millions and $£ 31 / 2$ millions 
for the military defence of the colonies, including Canada: Would it have been wonderful if an Englishman at the time had argued: "If we are to be taxed to pay Canada's defence bill and, while admitting Canadian goods free, to have our goods taxed in Canada, where does the value of the connection come in?"

Once again, is it wonderful if some thinking Englishmen, when pondering over the problem how colonial independence could possibly be combined with imperial unity, and not being gifted with second sight, may have concluded that the end must be severance of the colonies from the Empire? The problem is still with us. Hear Sir Robert Borden: "Canadians of great eminence and distinguished ability have entertained a sincere opinion that the ultimate goal is complete independence as a separate nation. In some instances such opinions have been modified or withdrawn; in no case should they incur reproach or contempt." What about the reproach and contempt meted out to Englishmen in past days who felt any doubts of the kind? And are we wanting in vision when we now find difficulty in forecasting the future? But the words which have been quoted above as to the apparent relief of British statesmen in or about 1867 at the prospect of getting rid of British North America can be safely challenged as a wholly misleading generality. No British government would have lived for a day if it had proposed to get rid of Canada; the British nation could not have tolerated such an idea for a single moment.

Continuing our study of indifference and want of vision, let us look first at Lord Durham's time and then at the time of the British North America Act. Lord Durham is credited by Sir Robert with "wide vision". Among the blind he had one eye, but he contemplated certain limitations, which we all remember, to responsible government, and which call forth the comment: "That a man of Lord Durham's vision could not foresee the lamentable consequences of such limitations is remarkable." So it seems to us, wise after the event, but is not the fact that this truly great and farseeing man did not foresee them, in itself, an answer to all these facile charges about want of vision? Even the broadest-minded men can only see through a glass darkly, when they look into the future. However, we can all agree that Lord Durham was, at any rate- shall we say-the best of a bad lot. Now let us turn to the quotation which is given from a speech of the more benighted Lord John Russell, made in 1837 before the Durham Mission: "We consider that these demands 
[for an Executive Council responsible to the House of Assembly and not to the government or Crown of Great Britain] are inconsistent with the relations between a colony and the Mother Country, and that it would be better to say at once, Let the two countries separate, than for us to pretend to govern the colony afterwards." Lord Durham thought that responsible government could be limited, and that the ultimate power over Canada could be shared between the Mother Country and Canada. Lord John Russell thought that, with the grant of responsible government, the power over Canada would pass wholly away from the Mother Country to Canada. Which of the two men apprehended more accurately what responsible government involved? And is it wonderful that, realizing what responsible government meant, Russell and his colleagues approached it, eighty years ago, in the most cautious and tentative manner?

Coming on to the time of the passing of the British North America Act, we have seen that the Mother Country was considered capable of combining indifference to the colonies with repression of the colonies. It was perfectly certain that, whatever was done or left undone, one or the other or both charges would be made. Alleged indifference was likely to make less mischief than alleged interference. In this particular case it was the charge of indifference that was laid. The secretary of state for the colonies, Lord Carnarvon, was, as was more often than not the case, in the House of Lords, and it is found convenient to overlook his speeches on Canadian confederation in that House and outside. Yet it would be difficult to detect want of appreciation of Canada in his speech on the second reading of the bill: "We are laying the foundation of a great State, perhaps one which at a future date may even overshadow this country. But, come what may, we shall rejoice that we have shown neither indifference to their wishes nor jealousy of their aspirations, but that we, honestly and sincerely, to the utmost of our power and knowledge, fostered their growth, recognizing in it the conditions of our own greatness." Not a bad effort for the accredited official spokesman of an indifferent and visionless Mother Country! But the gravamen of the charge of indifference, apparently, lay largely in the bill not being made more of in the House of Commons. Lord Carnarvon's speeches give the clue. The bill had been elaborately and painfully worked out. It was of the nature of a compromise. Canadian opposition to it was 
present in England. The one thing needful was to get it through parliament, if possible, as it stood. That object was achieved, the Canadians got what they wanted, and they went on their way rejoicing and complaining of the indifference of the Mother Country.

"It may be," writes Sir Robert Borden, "that British statesmen learnt the wrong lesson from the American Revolution." What was the right lesson of the American Revolution? That, when British citizens have formed communities overseas with representative institutions, for the Mother Country to try to make them pay for their own defence by herself imposing taxes on them is to invite the deluge. Does the history of defence in or of Canada show that British statesmen had learnt the lesson, or does it not? One more point. The time-honoured or dishonoured maxim of past Empires was Divide et impera. Did the Mother Country ever act on this maixm? Did it ever within the limits of the present Empire do other than favour and encourage the formation of larger units? I can only think of one instance, and that was of a special kind, when Sir George Grey's plan for federating the Cape Colony with the Orange Free State was turned down. But then, of course, the encouragement of larger units was only another sign of indifference and born of a desire to get rid of the colonies!

I repeat that the above to me is no true rendering of history. It has as much or as little truth as the one-sided version of which it is the other side. This is put forward, because it is such a pity that coming generations of Canadians should be fed up with the doctrine that they are what they are in spite of the Mother Country, and not with her goodwill.

All of which is submitted by an old country citizen who is at least as proud of Canada as any Canadian can be, and who has high admiration for Sir Robert Borden.

C. P. LuCAS 